\title{
Landscape analysis of the family planning situation in Pakistan-District profile: Karachi
}

Population Council

Follow this and additional works at: https://knowledgecommons.popcouncil.org/departments_sbsr-rh

Part of the Demography, Population, and Ecology Commons, Family, Life Course, and Society Commons, and the International Public Health Commons How does access to this work benefit you? Let us know!

\section{Recommended Citation}

"Landscape analysis of the family planning situation in Pakistan-District profile: Karachi." Islamabad: Population Council, 2016. 


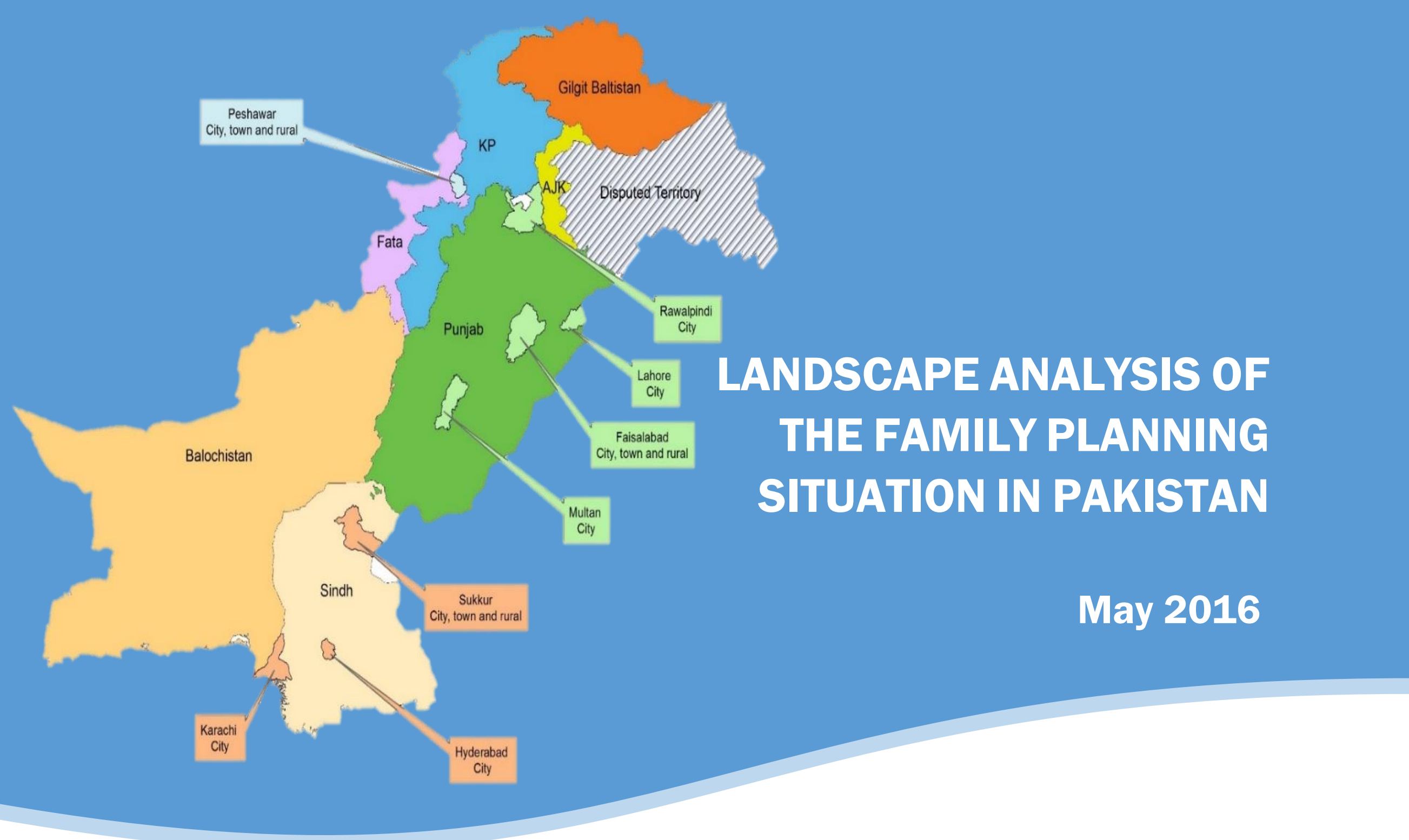

DISTRICT PROFILE: KARACHI

BILL\& MELINDA

GATES foundation

POPULATION COUNCIL

Ideas. Evidence. Impact. 


\section{Background}

Karachi is situated at the southeastern tip of the province of Sindh (Figure 1). With an estimated population of 18.8 million, ${ }^{1}$ Karachi is the largest city of Pakistan. It is the business, educational, and political hub of the country and also houses the largest port. Administrative divisions of the city include five districts, namely Karachi East, Karachi West, Karachi Central, Karachi South, and District Malir.

Table 1 presents basic demographic facts about the city. Of 5 million reproductive aged women, 3 million are married. At 52, the infant mortality rate (IMR) of Karachi is much lower than Sindh's average (82).

Table 1: Demographics of Karachi

\begin{tabular}{|l|l|}
\hline Demographics & Karachi \\
\hline Total population & $18,789,000$ \\
\hline Women 15-49 (N) & $4,977,000$ \\
\hline MWRA (N) & $3,087,000$ \\
\hline Literacy rate (10 years and above)* & $82 \%$ \\
\hline IMR** & 52 \\
\hline $\begin{array}{l}\text { Source: Sindh Development Statistics 2013, * Pakistan Social and } \\
\text { Living Standards Measurement Survey (PSLMS) 2014-15, ** } \\
\text { Multiple Indicator Cluster Survey (MICS) Sindh 2014 }\end{array}$ \\
\hline
\end{tabular}

Karachi's total fertility rate (TFR), 3.0, is much lower than Sindh's average (4.0). However, the TFR ranges widely among the districts of Karachi (Figure 2), being lowest in the South (2.4) and highest in Malir (3.9).
Figure 1: Map of Karachi

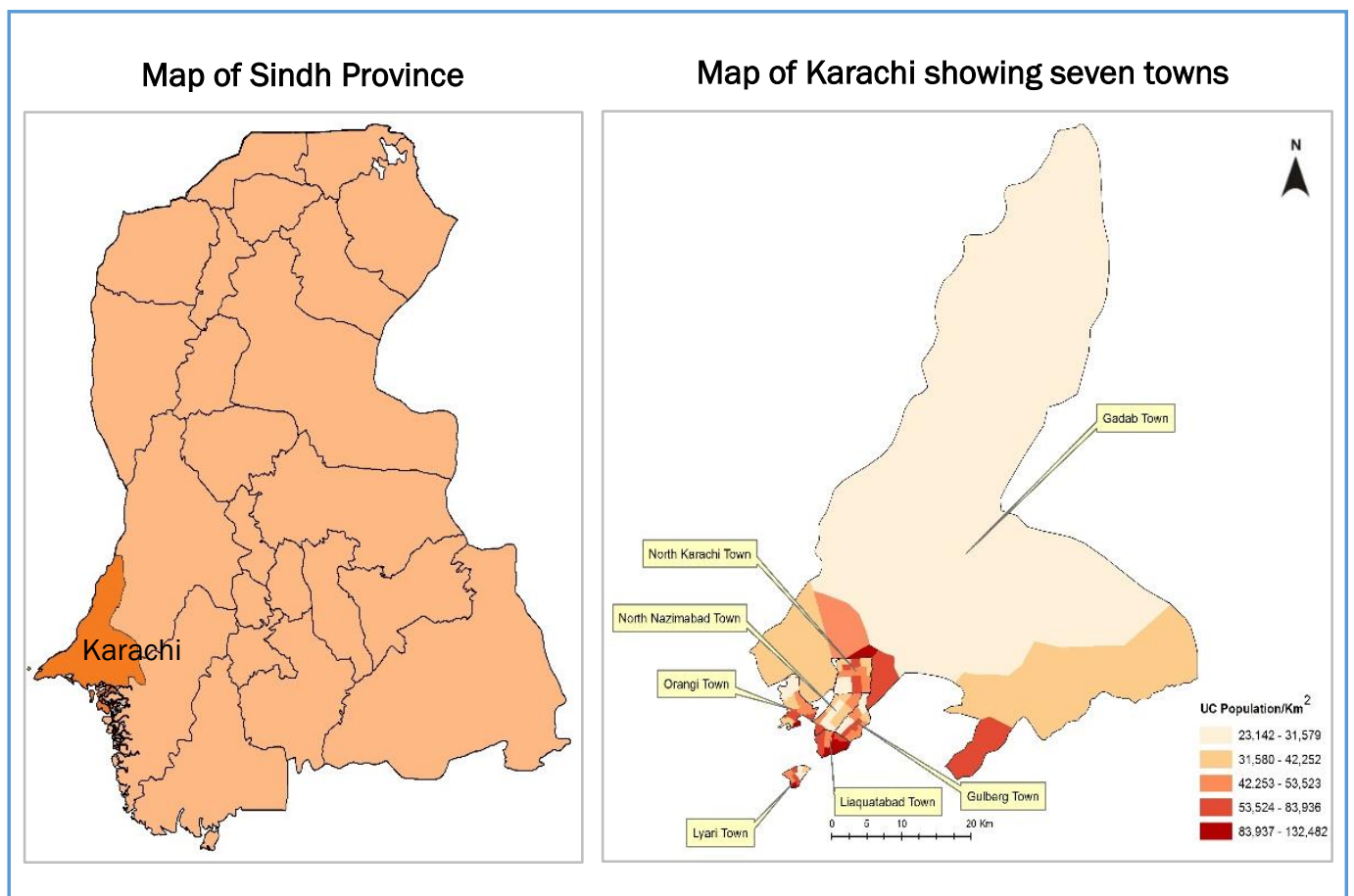

Figure 2: Total fertility rates in Karachi, by district

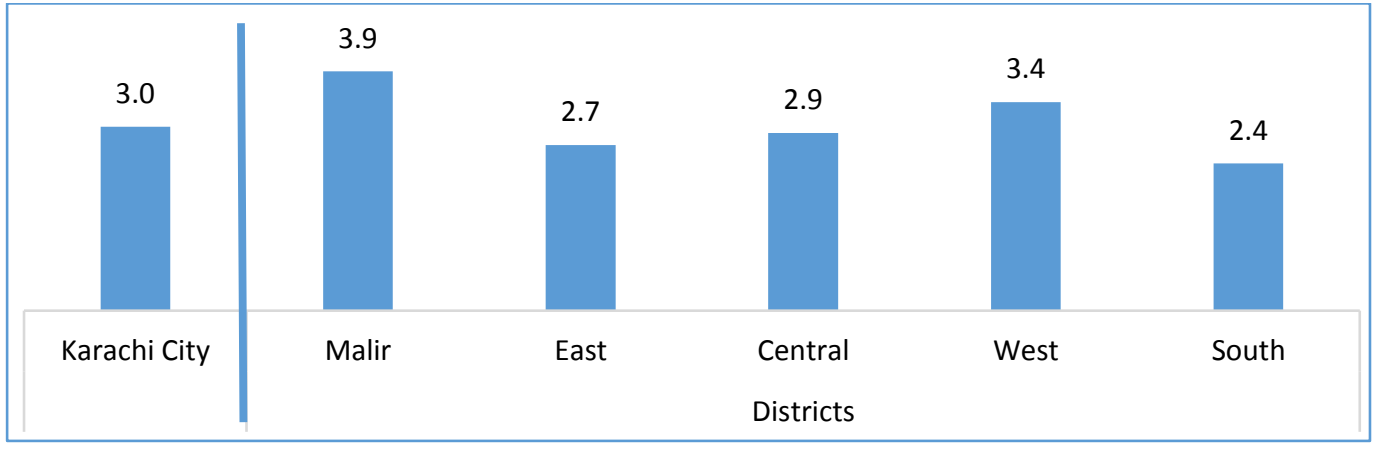

Source: Multiple Indicator Cluster Survey (MICS) Sindh 2014 


\section{Use of Family Planning}

Overall, 39 percent of couples ${ }^{2}$ are using any contraceptive method and 30.5 percent are modern method users. The unmet need for family planning is still high at 20.5 percent. Contraceptive use varies across the five districts: it is lowest in Karachi West (32.9\%) and highest in Karachi South (47.2\%) (Figure 3). Unmet need for family planning is negatively associated with contraceptive use, and is highest in Karachi West (26.6\%) and lowest in Karachi South (13.2\%)

Figure 3: Contraceptive use and Unmet Need in Karachi and Districts

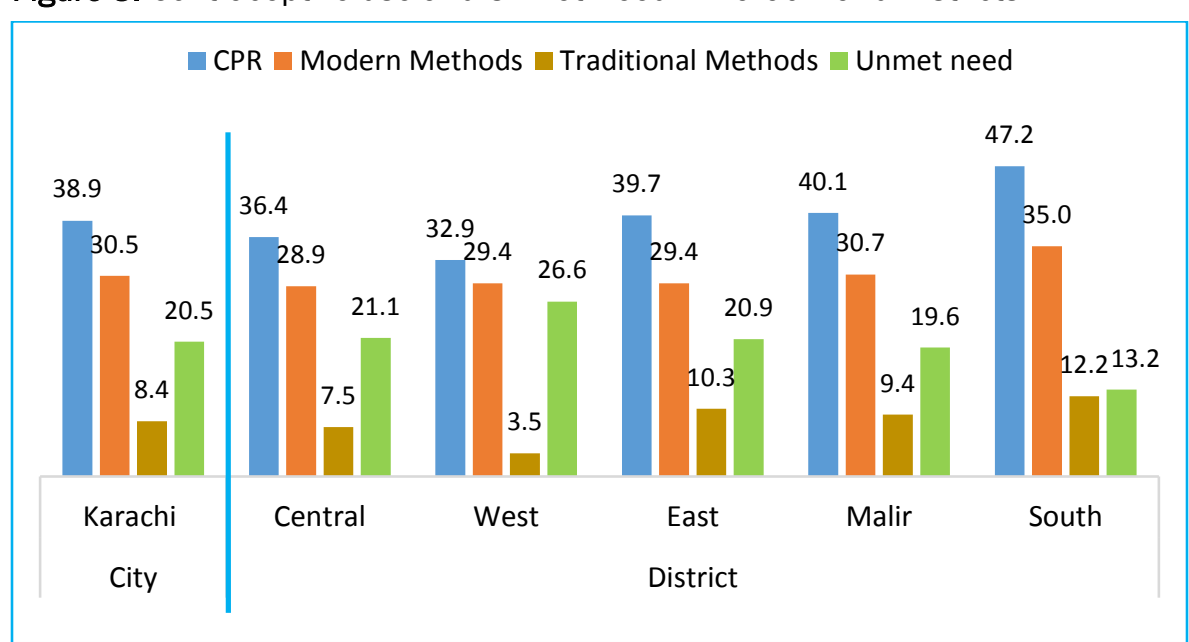

\section{Use of Antenatal and Dellvery Care Services}

As expected, women's healthcare seeking behavior is much better than other urban centers of the country: 95 percent of married women ${ }^{3}$ sought antenatal health care during their last pregnancy; 88 percent of the deliveries took place in an institution, most of them were delivered in a private health facility (68\%).

\section{Other Socloeconomic Indicators}

The literacy rate (10 years and above) in Karachi is 82 percent. However, the male literacy rate is 7 percentage points higher than the female literacy rate (72\%). Interestingly, the literacy rate among reproductive aged women is as high as 85 percent. Overall 93 percent of the households own television sets, and most of the households (96\%) either own mobiles or landline phones. The main material used for the roofs is reinforced cement concrete (RCC) or reinforced bricks concrete (RBC), which is used by around three quarters of the houses. The walls of almost 100 percent of the houses are made of burnt bricks or block. The indicators show that the vast majority of households are in fairly good socio economic condition.

\section{Avallability of Health Facilities and LHWs}

A census of public and private health facilities and providers was carried out in seven townships of Karachi namely Gadap Town, Gulberg Town, Liaquatabad Town, Lyari Town, North Karachi Town, North Nazimabad Town and Orangi Town in 2010 under the USAID-funded Family Advancement for Life and Health (FALAH) and Packard Foundation funded projects. Figure 4 shows the overall share of the available public and private health facilities: private facilities outnumber public facilities; Lady Health Workers (LHWs) also comprise 28 percent of all health services in these areas.

Figure 4: Distribution of health facilities and LHWs in seven towns of Karachi by sector, 2010

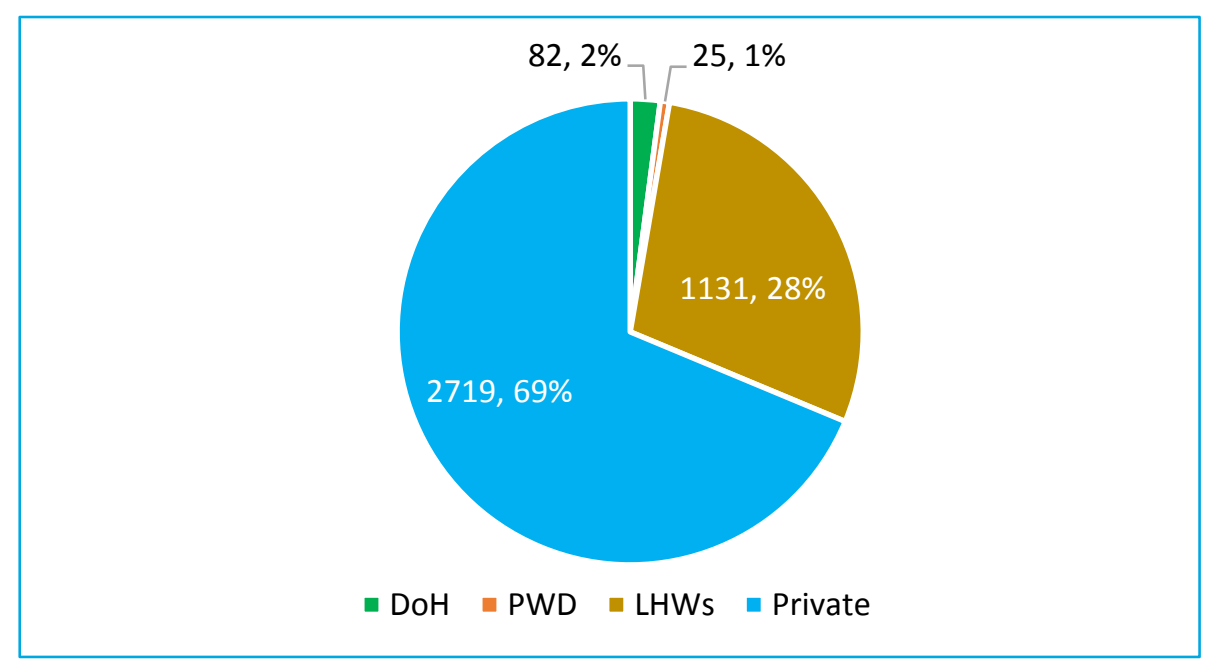

\section{Distribution of Public Static Facllities by Cadre}

Figure 5 shows the distribution of public static facilities in Karachi: there is a very large number of public dispensaries (64\%) followed by public hospitals $(27 \%)$. 
Figure 5: Cadre-wise distribution of static public facilities in seven towns of Karachi by sector, 2010

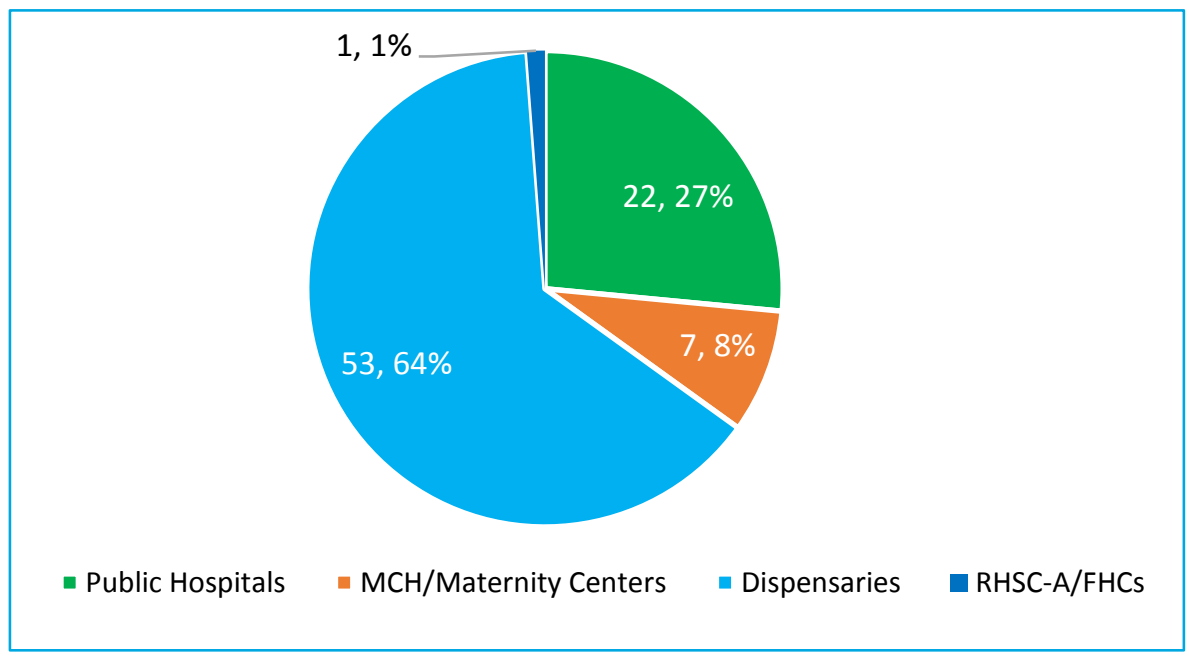

\section{Distribution of Private Facllities by Cadre}

Figure 6 shows the distribution of private facilities in Karachi. Clinics of male doctors are largest in numbers (38\%) followed by homeopath/hakeem clinics (33\%) and private hospitals (11\%)

\begin{tabular}{|c|c|c|c|c|c|c|c|c|c|}
\hline Sector & Condoms & OCPs & Injectables & IUDs & ECPs & Implants & $\begin{array}{l}\text { Female } \\
\text { Sterilization }\end{array}$ & $\begin{array}{l}\text { Male } \\
\text { Sterilization }\end{array}$ & Number of Facilities \\
\hline DoH & 72 & 94 & 83 & 25 & 3 & 6 & 3 & 3 & 36 \\
\hline PWD & 100 & 100 & 100 & 84 & 4 & 0 & 4 & 0 & 25 \\
\hline LHWs & 100 & 100 & 55 & NA & NA & NA & NA & NA & 1,131 \\
\hline Private & 72 & 90 & 88 & 42 & 38 & 3 & 6 & 2 & 861 \\
\hline
\end{tabular}

Figure 6: Cadre-wise distribution of private facilities in seven towns of Karachi, 2010

\section{Provislon of Speciflc Family Planning Methods by Sector}

Table 2 shows how different sectors perform in providing specific family planning methods. Most facilities of the Department of Health ( $\mathrm{DoH})$ are providing condoms, oral pills, injectables and IUDs. The facilities of the Population Welfare Department (PWD) are providing the full range of methods, while LHWs are almost fully providing condoms, pills and the second/subsequent dose of injectables. Considerable proportions of private facilities are providing condoms, oral pills and injectables; lesser numbers are providing intrauterine devices (IUDs) and emergency contraceptive pills (ECP), despite the urban setting of Karachi.

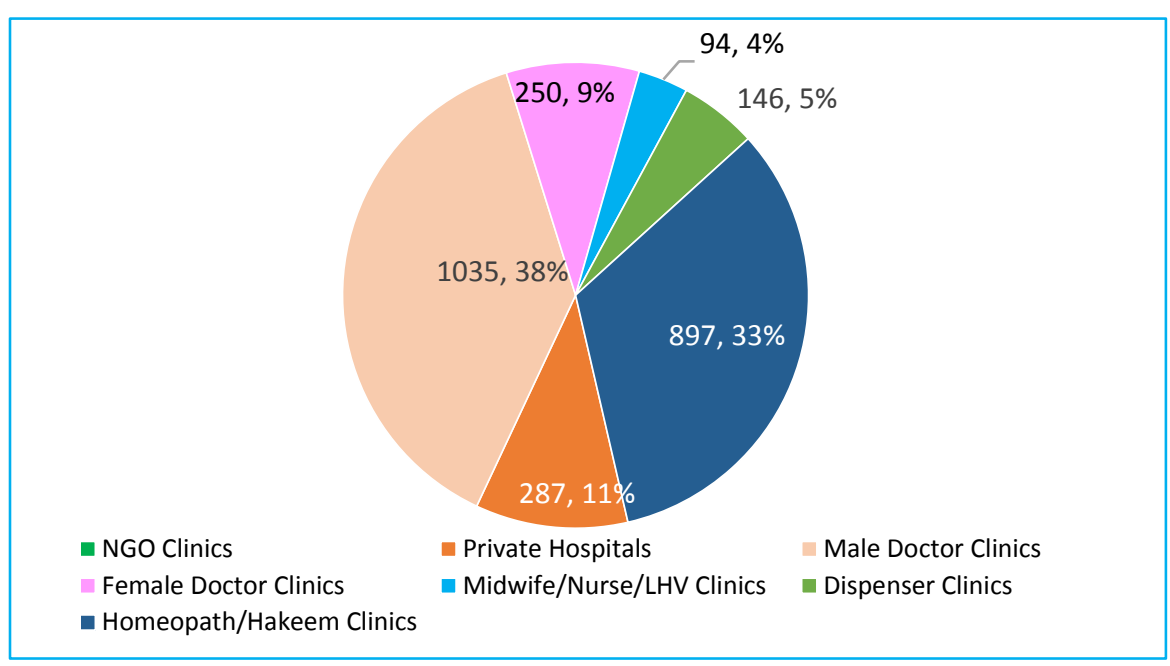

Table 2: Provision of specific family planning methods by sector in seven towns of Karachi, \%, 2010

NA: Not applicable ECP: emergency contraceptive pill IUD: intrauterine device OCP: oral contraceptive pill 


\section{Presence and Provision of FP Services: A Comparison}

Figures 7 and 8 present pairs of maps showing the presence of public health facilities and private health facilities, and also their status of provision of at least one family planning method in 2010. Figure 7 shows that, collectively, 79 percent of the 107 public health facilities were providing family planning services, although they are all mandated to provide this service.

Figure 7: Proportion of public static facilities providing at least one FP service in seven towns* of Karachi, 2010
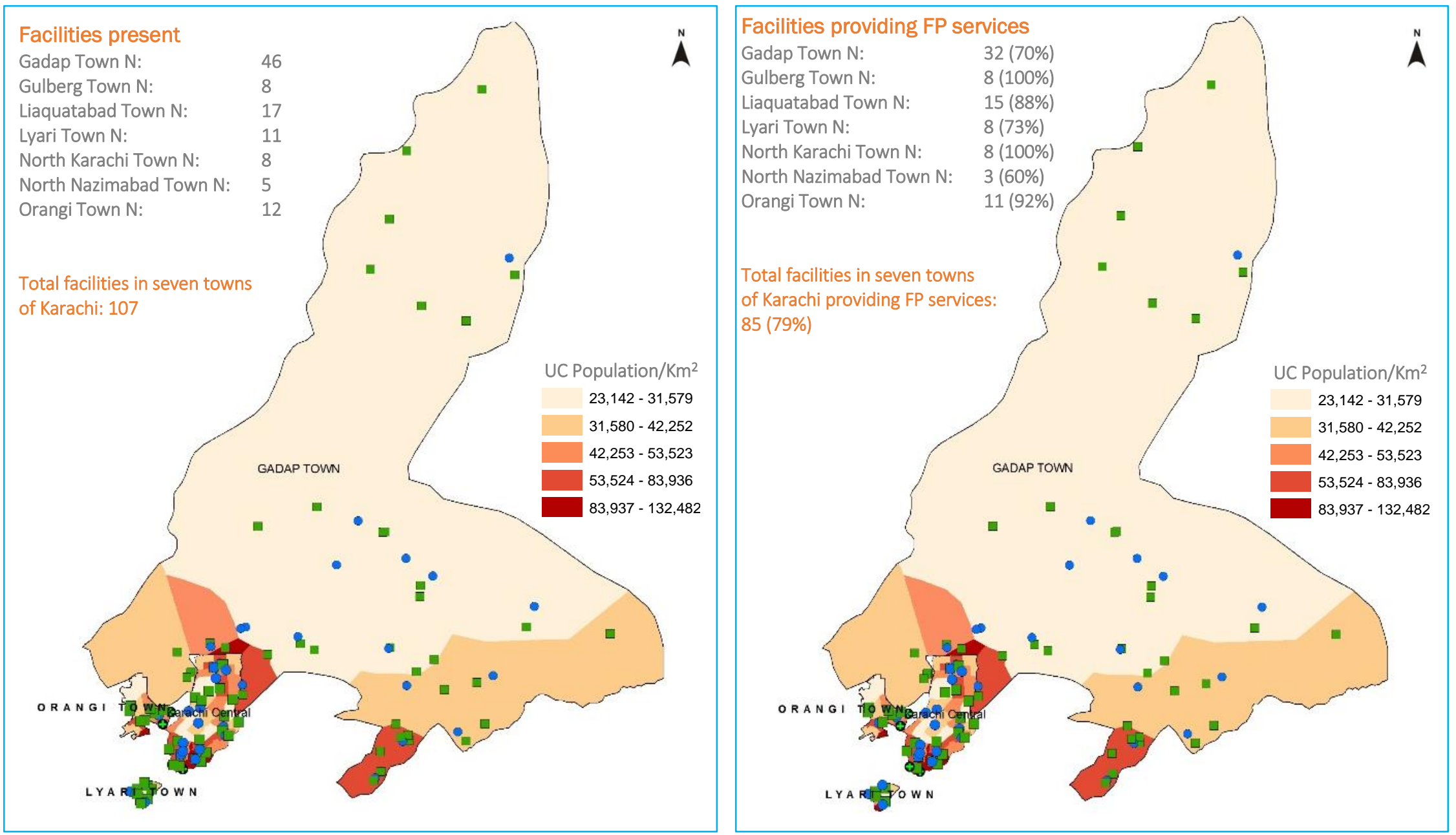

[. Department of Health (DoH)

- People's Primary Health Care Initiative (PPHI)

- Population Welfare Department (PWD)

* Towns: Gadap Town, Gulberg Town, Liaquatabad Town, Lvari Town, North Karachi Town, North Nazimabad Town and Orangi Town 
Among private health facilities, the proportion providing any family planning services dropped to 71 percent (Figure 8). But due to their greater numbers, more than 22 times as many private facilities were found to be providing any family planning services as public facilities in Karachi.

Figure 8: Proportion of private facilities providing at least one FP service in seven towns* of Karachi, 2010
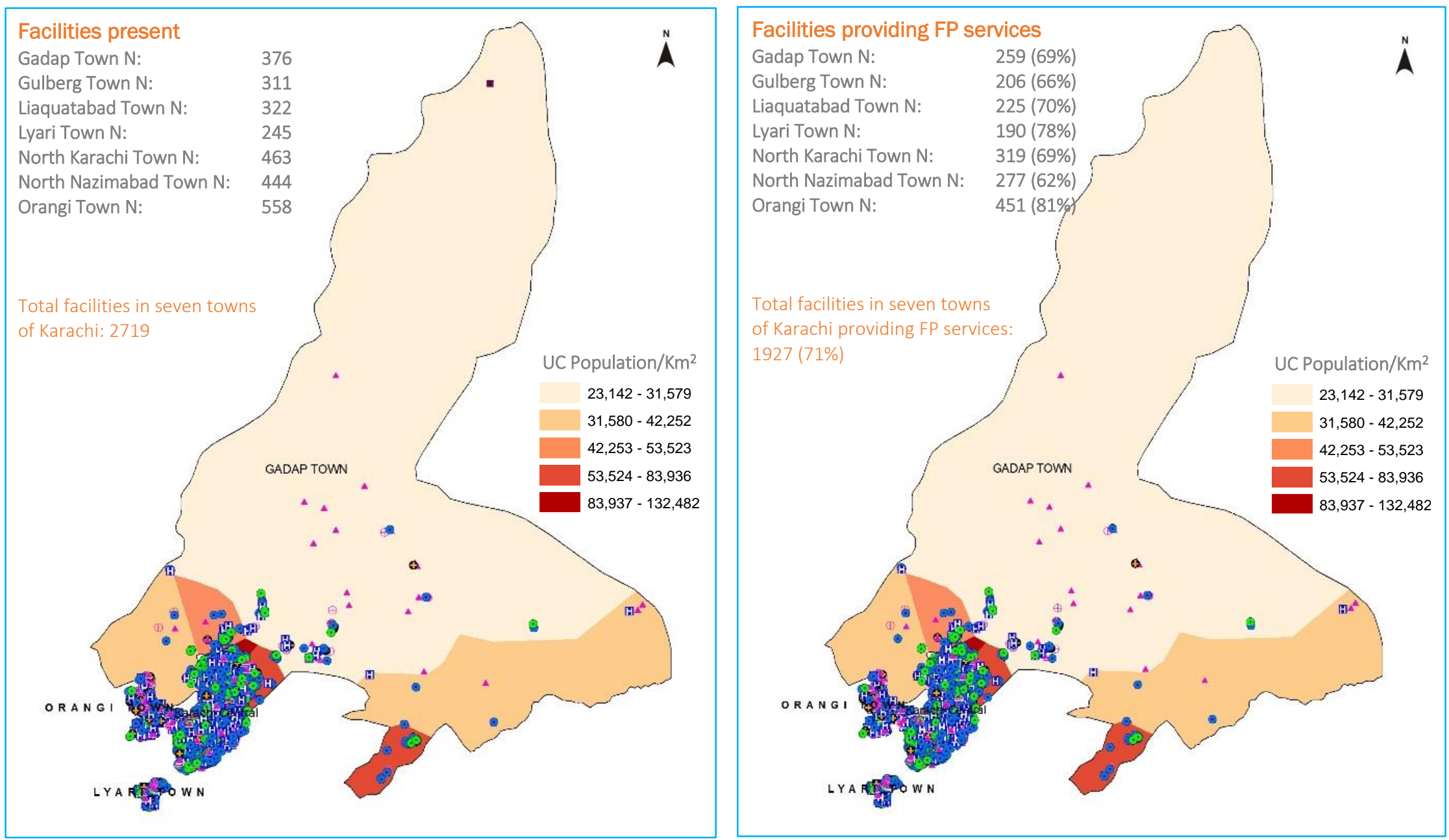

If Private Hospitals

- Male Doctor Clinics

- Female Doctor Clinics
- LHV/Nurse/Midwife Clinics

4. Dispenser Clinics

$\oplus \quad$ Homeopath/Hakeem Clinics

* Towns: Gadap Town. Gulberg Town. Liaquatabad Town, Lvari Town. North Karachi Town. North Nazimabad Town and Orangi Town 


\section{Consumer Perspectives on Barriers to Use of Family Planning}

In Karachi, we conducted in-depth interviews (IDIs) with men and women in eight communities of Malir, Gadap Town, Karachi East and Karachi West in 2015. A total 59 respondents participated in discussions through 33 IDIs (with 7 men and 26 women) and 3 focus group discussion ( 2 with men and 1 with women) in these communities. The majority of the communities are poor, and major income sources are fishery and home-based small industries. Family planning services were being provided in these communities at the doorstep through different NGOs, like AMAN Foundation and HANDS.

Respondents cited four main barriers to the use of family planning. Two of these, including lack of family planning information and services for men and financial barriers for poor couples, were reported to have a strong impact. The other two barriers, i.e., poor quality of services at public facilities, and limitations of access, influencing method mix, were considered to exert a medium level of influence by respondents.

\section{Lack of information for men}

- Men cannot find any direct sources of method-specific information; this limits their choices.

- They have limited information about a few family planning methods but do not get complete information.

"Doctors advised us to use family planning but our family members say that family planning methods are harmful so we do not use. I also feel shy discussing family planning so I could not take advice from anyone." Male, Karachi city

- Men tend to be busy in economic activities and have less time to talk to others about family planning.

- There is also a strong tradition of privacy about intimate/personal matters concerning the spouse; therefore men are shy about discussing family planning. They also fear negative social reactions.

"People do get offended if we talk to each other about personal matters... If I ask my friend what method he is using, he might say, 'Why are you asking me?'” Male, Karachi city
- Men find it difficult and embarrassing to purchase condoms from shop in the presence of others.

"Whenever my husband goes to the store there are four, five other people present and he feels embarrassed asking in front of them. And if someone else is asking for condoms, the shopkeeper passes comments like 'You are going to have a good night.' Condoms are a good method but it's hard to buy them from the store because of shopkeepers' comments." Female, Karachi city

Cost - a serious barrier for poor men and women struggling to continue use

- Costs are the second major barrier for poor men and women, for whom affording even condoms is not always easy.

- Although community workers are providing injectables to women, they can have stock outs; poor people cannot afford the price of injectables from private clinics.

- Women prefer to get injectables from their trusted service providers from whom they seek other health services, but it is difficult to manage the cost.

"My husband earns 400 to 500 rupees per day. I saved money. We have to pay the rent so we barely manage the daily expenditure. I managed the cost." Female, Karachi city

- Although women and men want to continue using contraceptive methods when they are satisfied with them, the increasing charges of providers make it difficult for them to continue use.

"Initially, I paid 80 rupees and later 120 and finally 300 rupees since the provider says there is too much inflation and the costs of injections have increased. The price rise will create difficulties." Female, Karachi city

- Poor women sometimes find it hard to afford even the nominal charges at public facilities or small out-of-pocket costs.

"I earned 100 rupees and I bought vegetables for 50 rupees and kept the rest for the children. But when I went to the hospital the provider asked for 50 rupees for the copper T. I had to give her the 50 rupees." Female, Karachi city 
Women's economic activity, increasing inflation, and NGOs working in the area are strong ideational factors for men and women

- Educated women are more likely to work at schools, medical facilities, and in private jobs and businesses, which expands their horizons and networks and makes it more likely that they want to use family planning.

- Many of the poorer women provide domestic services, work in small industries, and are involved in stitching for income; they often discuss their problems in detail with the women with whom they interact, including about family planning.
- Having to cope with growing expenses, such as increasing house rent and education, is pushing couples to adopt family planning. 


\section{District specific Donors, Projects and Implementing partners}

\begin{tabular}{|c|c|c|}
\hline Donor & Program/ Project Title & Implementing Partner \\
\hline \multirow{3}{*}{$\begin{array}{l}\text { Bill and Melinda } \\
\text { Gates } \\
\text { Foundation }\end{array}$} & $\begin{array}{l}\text { Building Blocks for Family Planning in Pakistan - Developing a Costed Implementation Plan } \\
\text { for Sindh and Punjab, 2013-2015 }\end{array}$ & Pathfinder International \\
\hline & Sukh Initiative, 2014-2018 & $\begin{array}{l}\text { Aman Health Care } \\
\text { Co-partners: } \\
\text { Aahung, AMANTELEHEALTH, Jhpiego, } \\
\text { Aga Khan University }\end{array}$ \\
\hline & Landscape Analysis of Family Planning in Pakistan, 2015-2016 & Population Council \\
\hline \multirow{7}{*}{$\begin{array}{l}\text { The David \& } \\
\text { Lucile Packard } \\
\text { Foundation }\end{array}$} & Sukh Initiative, 2014-2018 & $\begin{array}{l}\text { Aman Health Care } \\
\text { Co-partners: } \\
\text { Aahung, AMANTELEHEALTH, Jhpiego, } \\
\text { Aga Khan University }\end{array}$ \\
\hline & $\begin{array}{l}\text { Increasing Access and Use of Contraceptives in Punjab/Sindh: Keeping Momentum \& } \\
\text { Innovating for Success, 2012-2015 }\end{array}$ & DKT Inc \\
\hline & Achieving MDG5 - Continuing Momentum, Building Champions, 2012-2015 & Shirkat Gah Women Resource Centre \\
\hline & $\begin{array}{l}\text { Quality Family Planning and Reproductive Healthcare Through Community Mobilization: } \\
\text { From Rhetoric to Reality, 2013-2015 }\end{array}$ & Strengthen Participatory Organization \\
\hline & Empowering Girls - Transforming Communities: From Awareness to Action, 2013-2016 & Rutgers WPF \\
\hline & $\begin{array}{l}\text { Creating an Enabling Environment to Promote Sexual and Reproductive Health and Rights, } \\
\text { 2013-2015 }\end{array}$ & Aahung \\
\hline & Strengthening and Sustaining Postpartum Family Planning in Pakistan. 2013-2015 & Johns Hopkins University (JHU) - JHPIEGO \\
\hline \multirow[t]{4}{*}{ USAID } & DELIVER Project, 2008-2016 & $\begin{array}{l}\text { Planning Commission of Pakistan } \\
\text { Ministry of Health (MOH) } \\
\text { Provincial and regional departments of health and population } \\
\text { UNFPA } \\
\text { NGOs }\end{array}$ \\
\hline & Family Planning and Reproductive Health Services, 2013-2017 & Marie Stopes Society \\
\hline & Health Communication, 2014-2019 & JHUCCP \\
\hline & Health System Strengthening & JSI Research \& Training Institute, Inc \\
\hline \multirow[b]{2}{*}{ UNFPA } & Capacity Building of Female Service Providers Enhanced in Family Planning, 2014-2017 & $\begin{array}{l}\text { Population Welfare Departments } \\
\text { MNCH Programs } \\
\text { LHWs Program }\end{array}$ \\
\hline & $\begin{array}{l}\text { Advocacy for Universal Access to Reproductive Health and to Integrate in Provincial Health } \\
\text { Policies, Plans and Budgetary Frameworks, 2012-2017 }\end{array}$ & $\begin{array}{l}\text { Population Welfare Departments } \\
\text { Population Council } \\
\text { Pathfinder } \\
\text { Ministry of National Health Services, Regulations and Coordination }\end{array}$ \\
\hline WHO & $\begin{array}{l}\text { Providing Technical Assistance to Develop a Unified Care Providers Manual on FP based on } \\
\text { the WHO Handbook on FP }\end{array}$ & $\begin{array}{l}\text { Ministry of National Health Services Coordination and Regulation } \\
\text { MNCH programs } \\
\text { UNFPA, Population Council, GIZ, USAID etc. }\end{array}$ \\
\hline $\begin{array}{l}\text { Large Anonymous } \\
\text { Donor (LAD) }\end{array}$ & $\begin{array}{l}\text { Increasing Access to and Use of Long Term Methods of FP and PAC Services in Pakistan, } \\
\text { 2014-16 }\end{array}$ & Greenstar Social Marketing \\
\hline
\end{tabular}

